\title{
Effects of low dissolved oxygen on predation on estuarine fish larvae
}

\author{
Denise L. Breitburg ${ }^{1}$, Nancy Steinberg ${ }^{2, *}$, Sarah DuBeau $^{2, * *}$, Cynthia Cooksey ${ }^{2, * * *}$, \\ Edward D. Houde ${ }^{2}$
}

\author{
${ }^{1}$ The Academy of Natural Sciences, Benedict Estuarine Research Laboratory, Benedict, Maryland 20612, USA \\ ${ }^{2}$ The University of Maryland System, Center for Environmental and Estuarine Studies, Chesapeake Biological Laboratory, \\ Solomons, Maryand 20688, USA
}

\begin{abstract}
Low dissolved oxygen concentrations, caused by density stratification of the water column and excess nutrient inputs, occur in many aquatic habitats. Laboratory experiments we conducted indicated that low dissolved oxygen has the potential to strongly alter the absolute and relative importance of a suite of estuarine predators of fish larvae. At dissolved oxygen concentrations $\leq 2 \mathrm{mg}^{-1}$, predation on naked goby Gobiosoma bosc larvae by an important invertebrate predator of plankton in Chesapeake Bay (the sea nettle scyphomedusa Chrysaora quinquecirrha) increased. In contrast, at the same oxygen concentrations, predation by 2 vertebrate predators, juvenile striped bass Morone saxatilis and adult. naked goby, decreased. Changes in consumption of larvae most likely resulted from impaired ability of larvae to escape the scyphomedusa, and decreased attack rates by adult and juvenile fishes. Fish predators increased gill ventilation rates even at oxygen levels higher than those leading to decreased predation. However, we could detect no comparable change in behavior of the sea nettle even at $1 \mathrm{mg} \mathrm{l}^{-1}$, the lowest oxygen concentration tested. The observed changes in trophic interactions occurred at dissolved oxygen concentrations that are not lethal during short exposures, and that commonly occur in the Chesapeake Bay and other eutrophic estuaries during summer. Thus, low oxygen has the potential to cause significant changes in the importance of alternate trophic pathways in estuarine systems.
\end{abstract}

KEY WORDS: Chesapeake Bay - Fish larvae - Hypoxia - Naked goby Predation Scyphomedusa . Striped bass

\section{INTRODUCTION}

The persistent or episodic occurrence of low dissolved oxygen (hypoxia) is an important physical feature of many aquatic habitats including eutrophic estuaries and lakes, nearshore coastal waters, fjords, lakes experiencing winterkill conditions, and the oxygen minimum layer of the deep-sea. In shallow marine systems, hypoxia generally occurs during summer when density stratification of the water column limits reaera-

\section{Present addresses:}

- Marine Science Research Center, State University of New York at Stony Brook, Stony Brook, New York 11794, USA

“200 Brandy Hill Road, Vernon, Connecticut 06066, USA

...Virginia Institute of Marine Science, College of William and Mary, Gloucester Point, Virginia 23062, USA tion of bottom waters (Renaud 1986, Turner et al. 1987, Swanson \& Parker 1988, Rabalais et al. 1991). Oxygen depletion in these estuaries and coastal waters is often exacerbated by excess nutrient loadings (Officer et al. 1984, Boesch 1987, Elmgren 1989, Rosenberg et al. 1990), and is predicted to become more common in the event of global warming (Kennedy 1990).

In this paper we describe experiments that examined how low dissolved oxygen affects the vulnerability of fish larvae to their important predators in the Chesapeake Bay, USA, and in estuaries along much of the east coast of North America. Dissolved oxygen concentrations in much of the mesohaline Chesapeake Bay are below 50\% saturation during the summer (e.g. Officer et al. 1984, Price et al. 1985, Malone et al. 1986, Magnien et al. 1987). Such oxygen concentrations are physiologically stressful to many fish species (Rom- 
bough 1988), resulting in reduced larval survival, development and growth. (Siefert \& Spoor 1974, Rogers et al. 1982, US-EPA 1986, van der Veer \& Bergman 1986). Studies of freshwater teleosts indicate that low dissolved oxygen concentrations also can modify juvenile and adult growth rates, feeding rates, habitat use, and susceptibility to predation, as well as adult reproductive activities (Magnuson et al. 1985, Suthers \& Gee 1986, US-EPA 1986, Kramer 1987, Poulin et al. 1987, Saint-Paul \& Soares 1987). Low dissolved oxygen in Chesapeake Bay and its tributaries is thought to limit populations of ecologically and economically important finfish and shellfish species through both habitat restriction and direct mortality (Kemp \& Boynton 1981, Officer et al. 1984, Price et al. 1985, Breitburg 1988, 1992, Coutant \& Benson 1988, Osman et al. 1990).

Under current conditions, some Chesapeake Bay waters consistently reach oxygen concentrations that are rapidly lethal to most fish species. However, a larger volume of water has summer dissolved oxygen concentrations in the range of 1.0 to $4.0 \mathrm{mg} \mathrm{l}^{-1}$ (Jordan et al. 1992) - levels that are tolerable at least during brief exposures but that may alter feeding and swimming behaviors and long-term prospects for growth and survival (US-EPA 1986, D. C. Miller unpubl.).

The influence of moderate levels of hypoxia on trophic structure and species interactions in estuarine systems is not known. Experiments with freshwater fish and invertebrates (Poulin et al. 1987, Rahel \& Kolar 1990) and field sampling of estuarine fishes (Pihl et al. 1992) suggest that predator-prey interactions will be altered. This outcome should be expected because most aspects of trophic interactions are potentially influenced by low dissolved oxygen, e.g. the abundance and distribution of both predators and prey, the ability to capture prey, and the ability to avoid predation.

The net effect of low oxygen on predator-prey interactions should depend on individual responses of all strongly interacting species and life stages. For example, low dissolved oxygen concentrations could be beneficial to a predator if the primary effect were to increase the vulnerability of its prey. In contrast, low dissolved oxygen could have a net detrimental effect on a predator that requires higher oxygen levels for efficient prey capture than is required by its prey for efficient escape behavior. Because vertebrate and invertebrate predators vary in both physiology and behavior, it might be expected that their predatory capabilities would be affected differently by low oxygen concentrations. Our results suggest that even within a single estuarine food web, low oxygen can lead to increased prey capture by some predators, but decreased prey capture by others, thereby potentially leading to important shifts in carbon flow in the ecosystem.

\section{Study organisms}

We used larvae of the naked goby Gobiosoma bosc as prey. Larvae of the naked goby are very abundant from late spring through summer in the Chesapeake Bay and its tributaries (e.g. Academy of Natural Sciences 1981, Olney 1983, Shenker et al. 1983), as well as in many estuarine systems along the Atlantic and Gulf of Mexico coasts of the United States (e.g. Allen \& Barker 1990). Small forage species such as the naked goby reproduce within the Chesapeake Bay and its tributaries when low dissolved oxygen conditions are severe, and produce larvae that can be exposed to hypoxic conditions throughout their development. Naked goby larvae hatch from benthic eggs, which are attached primarily to the inside of articulated oyster shells (Nero 1976). Larvae are found throughout the water column during most of their development, but prior to settlement they undergo a demersal schooling phase when they are abundant within a few $\mathrm{cm}$ of the substrate of oyster reefs (Breitburg 1989, 1991).

Adult naked goby, juvenile striped bass Morone saxatilis, and a scyphomedusan, the sea nettle Chrysaora quinquecirrha, were selected as predators. Adults of the naked goby are abundant benthic fishes in oyster reefs in the Chesapeake Bay. They eat a variety of mobile invertebrate taxa (Nero 1976), and their proximity to demersal and settling naked goby larvae, as well as the occasional observation of these rapidly digested prey in their guts (Nero 1976), suggest that cannibalism may be a significant source of larval mortality. Juvenile striped bass are opportunistic predators that consume a wide range of planktonic and benthic prey (Markle \& Grant 1970, Boynton et al. 1981. SetzlerHamilton \& Hall 1991\}. Fish larvae compose a major portion of the diet of juvenile striped bass, and naked goby larvae can, at times, be their main prey (Markle \& Grant 1970). The sea nettle is believed to be a major predator on plankton in the Chesapeake Bay (Cargo \& Shultz 1966, Feigenbaum \& Kelly 1984, Purcell 1992) and a key link in the Bay system that provides topdown control on plankton productivity, perhaps in the mainstem Bay (Baird \& Ulanowicz 1989), but especially in its tributaries (Purcell 1992). Peak periods of abundance of this scyphomedusan coincide both with the period of the most severe hypoxia and the highest abundances of naked goby larvae (Massman et al. 1963, Cargo \& Schultz 1967, Olney 1983, Shenker et al. 1983, Dalton 1987). Laboratory and mesocosm studies indicate that sea nettles may be the most important predator on fish larvae in the Chesapeake Bay (Cowan \& Houde 1992, 1993). In other systems, predation by siphonophores and cnidarian medusae may lead to larval mortality rates as high as 60 to $97 \% \mathrm{~d}^{-1}$ (Purcell 1984, 1985, Purcell \& Grover 1990). 


\section{METHODS}

Larval culture. Goby eggs and the egg-guarding males were collected from the field during May to August. Egg-guarding males were kept isolated with the nest until eggs hatched. Larvae were cultured in $75 \mathrm{l}$ tanks maintained at 24 to $28^{\circ} \mathrm{C}$. Larvae were fed the rotifer Brachionus plicatilis at nominal prey densities of $2000 \mathrm{l}^{-1}$ for the first $2 \mathrm{wk}$ posthatch. Older larvae were fed brine shrimp Artemia sp. nauplii at nominal densities of $500 \mathrm{l}^{-1}$. Culture methods were similar to those described for the bay anchovy Anchoa mitchilli (Houde 1977, 1978).

Collection and maintenance of predation. We collected adult naked gobies from the Patuxent River near Solomons, Maryland, USA. Adult naked gobies were maintained in the laboratory prior to use in experiments under ambient salinities ( 13 to $17 \mathrm{ppt}$ ) at 24 to $26^{\circ} \mathrm{C}$, and were fed frozen brine shrimp Artemia sp. Juvenile striped bass were obtained from the fish hatchery operated by the Potomac Electric Power Company at Chalk Point, Maryland. They were maintained in the laboratory prior to experiments at ambient salinities and temperatures, and were fed 'salmon chow' pellets at $10 \%$ body wt $\mathrm{d}^{-1}$. Sea nettles were collected by hand in the Patuxent River near Solomons, during the late afternoon or evening prior to experiments. They were held at 24 to $26^{\circ} \mathrm{C}$ and were not fed since they were collected close to the time of experiments.

Predation on fish larvae. Laboratory experiments were designed to test the effects of dissolved oxygen concentration on predator consumption rates on fish larvae. We only tested oxygen concentrations in which both larvae and predators survived exposures of at least several hours. Experimental tanks filled with $1 \mu \mathrm{m}$ filtered water from the mesohaline Patuxent River were bubbled with $\mathrm{N}_{2}$ or air: $\mathrm{N}_{2}$ mixtures to obtain desired dissolved oxygen concentrations. Predators were then added directly to the main part of the experimental tanks. Larvae were initially placed in separate plastic and mesh acclimation chambers. After predators and larvae were added, experimental tanks were sealed, and animals were acclimated to test dissolved oxygen concentrations for $1 \mathrm{~h}$. Larvae were then released into the main test arena and exposed to predators by tipping larval acclimation chambers via attached lines that ran through each tank lid.
All experiments utilized a randomized block design, such that each trial used a uniformly aged group of larvae from a single nest. Except as noted, only a single trial at each oxygen concentration was performed with each clutch (the blocking factor) and predators were not reused. Experiment duration, larval age, larval density and tank size varied among the 3 predators (Table 1). Our goal was to set conditions under which the predator could feed in a relatively natural manner but deplete no more than approximately $50 \%$ of the prey under saturated (control) oxygen concentrations.

Predation by adult naked gobies was tested only with postflexion larvae $(>7.3 \mathrm{~mm})$, which exhibited bottom-oriented behavior and would therefore be susceptible to cannibalism. Larvae used for these experiments were 24 to 28 days posthatch (dph) (Table 1), and thus did not vary appreciably in age among blocks. Smaller larvae are more often found higher in the water column where they would be unavailable to benthic adult and juvenile gobies. Striped bass and sea nettles were tested with the full range of larval stages because these predators feed throughout the water column. All predators were starved overnight prior to use in experiments.

At the end of each experiment, water from tanks was siphoned through a sieve, and all recovered larvae were collected and scored as live or dead. Sizes of predators [standard length (SL) for fish, bell diameter for sea nettles], and measured dissolved oxygen con-

Table 1. Experimental conditions for predation experiments. Experiment start and end data for temperature were first averaged for each replicate before summary statistics presented here were calculated. Size of predators is given as standard length for fish, and bell diameter for the sea nettle. Sat.: air-saturated; dph: days posthatch

\begin{tabular}{|c|c|c|c|}
\hline Experimental conditions & $\begin{array}{l}\text { Juvenile } \\
\text { striped bass }\end{array}$ & $\begin{array}{c}\text { Predator } \\
\text { Adult naked } \\
\text { goby }\end{array}$ & Sea nettle \\
\hline Type of experimental tank & Aquaria & Aquaria & $\begin{array}{l}\text { Cylindrical } \\
\text { plastic }\end{array}$ \\
\hline Size of experimental tank & 761 & 761 & $220 \mathrm{l}$ \\
\hline Duration of experiment & $35 \mathrm{~min}$ & $4 \mathrm{~h}$ & $2 \mathrm{~h}$ \\
\hline $\begin{array}{l}\text { Nominal oxygen } \\
\text { concentration tested }\left(\mathrm{mg} \mathrm{l}^{-1}\right)\end{array}$ & Sat., 4, 3, 2 & Sat., 3, 2, 1 & Sat., $3,2,1$ \\
\hline Measured temperature $\left({ }^{\circ} \mathrm{C}\right)$ & $25.9 \pm 0.2$ & $25.3 \pm 0.1$ & $25.8 \pm 0.1$ \\
\hline No. of replicate blocks tested & 13 & 4 & 7 \\
\hline No. of predators tank-1 & 1 & 3 & 1 \\
\hline $\begin{array}{l}\text { Size of predators } \\
{[\bar{x} \pm \text { SE (range) } \mathrm{mm}]}\end{array}$ & $\begin{array}{l}42.4 \pm 0.6 \\
(35-53)\end{array}$ & $\begin{array}{c}40.9 \pm 1.0 \\
(33-49)\end{array}$ & $\begin{array}{l}88.3 \pm 2.2 \\
(70-110)\end{array}$ \\
\hline No. of larvae & 40 & 20 & 50 \\
\hline Age of larvae (range: dph) & $0-24$ & $24-28$ & $1-22$ \\
\hline $\begin{array}{l}\text { Size of larva: notochord length } \\
\text { (range; } \mathrm{mm} \text { ) }\end{array}$ & $2.4-9.7$ & $7.3-10.0$ & $2.9-8.0$ \\
\hline
\end{tabular}


centrations and temperatures for each treatment are given in Table 2. Untransformed data (numbers of larvae consumed) were used for all statistical analyses of dissolved oxygen effects since variances were not heteroscedastic for any experiment $\left(F_{\max }\right.$ test, all $\mathrm{p}>$ 0.05 ). A posteriori tests were made with least-squares means comparisons.

Several deviations from the standard analysis and experimental design occurred in experiments utilizing sea nettles as predators. First, data from sea nettle experiments were analyzed in 2 ways, each making a different assumption about larvae that were dead and opaque upon retrieval. Opaque larvae had been dead for a longer period of time than it took for us to empty experimental containers, and were therefore not killed during the retrieval process. A total of $3,13,9$ and 25 dead, opaque larvae were retrieved from the control, $3 \mathrm{mg} \mathrm{l}^{-1}, 2 \mathrm{mg} \mathrm{l}^{-1}$ and $1 \mathrm{mg} \mathrm{l}^{-1}$ treatments, respectively. These larvae may have been killed by sea nettles but not consumed, or may have died as a result of handling. We feel it is likely that most of this mortality was due to contact with sea nettles. The larvae are unlikely to have died as a result of exposure to low oxygen since naked goby larvae survived longer exposures to $1.0 \mathrm{mg} \mathrm{l}^{-1}$ in related experiments (Breitburg unpubl.). Opaque larvae were rarely found in experiments with either of the predatory fishes. Because of the presence of these larvae, we analyzed data once reflecting larval mortality (opaque larvae included) and once reflecting sea nettle consumption (opaque larvae not included with those consumed). The results were qualitatively similar. Second, 1 clutch of larvae was used for 2 replicates, but since the ages and developmental stages differed ( 8 vs $22 \mathrm{dph}$, preflexion vs postflexion), these were considered to be independent replicates for statistical analyses. Finally, the $3 \mathrm{mg} \mathrm{l}^{-1}$ dissolved oxygen treatment was omitted in 1 of the 7 replicate blocks because of a shortage of experimental animals.

Effects of low dissolved oxygen on predator behavior. We were also interested in whether changes in consumption rates were due to changes in the behavior of predators or their prey. Gill ventilation rates were estimated for fish predators as an indicator of low oxygeninduced stress. Striped bass were placed in individual 761 aquaria. Dissolved oxygen concentrations were then reduced to target levels of $2.0,3.0$, and $4.0 \mathrm{mg} \mathrm{l}^{-1}$ by bubbling with $\mathrm{N}_{2}$. Control tanks were bubbled with air. Fish were acclimated to test oxygen levels for $1 \mathrm{~h}$, after which the number of operculum movements were

Table 2. Experimental conditions and predator sizes for predation experiments. na: treatments not done for that predator. Predator size was identical for all treatments with naked goby predators on amphipod prey because the same individuals were used for all oxygen concentrations tested. Experiment start and end data for dissolved oxygen were first averaged for each replicate before summary statistics presented here were calculated

\begin{tabular}{|c|c|c|c|c|c|c|}
\hline \multirow{2}{*}{$\begin{array}{l}\text { Predator: } \\
\text { prey }\end{array}$} & \multirow{2}{*}{ Variable } & \multicolumn{5}{|c|}{ Dissolved oxygen treatment } \\
\hline & & $1 \mathrm{mg}^{-1}$ & $2 \mathrm{mg} \mathrm{l}^{-1}$ & $3 \mathrm{mg} \mathrm{l}^{-1}$ & $4 \mathrm{mg} \mathrm{l}^{-1}$ & Control \\
\hline \multirow[t]{2}{*}{$\begin{array}{l}\text { Striped bass: } \\
\text { larvae }\end{array}$} & $\begin{array}{l}\text { Dissolved oxygen } \\
\left(\mathrm{mg} \mathrm{l}^{-1} ; \mathrm{n}=13\right)\end{array}$ & na & $2.05 \pm 0.02$ & $3.06 \pm 0.02$ & $4.01 \pm 0.02$ & $7.60 \pm 0.07$ \\
\hline & $\begin{array}{l}\text { Predator SL } \\
\left(m m ; n=12^{a}\right)\end{array}$ & na & $42.1 \pm 1.3$ & $41.8 \pm 1.2$ & $41.9 \pm 1.0$ & $43.7 \pm 1.0$ \\
\hline \multirow[t]{2}{*}{$\begin{array}{l}\text { Naked goby: } \\
\text { larvae }\end{array}$} & $\begin{array}{l}\text { Dissolved oxygen } \\
\left(\mathrm{mg} \mathrm{l^{-1 }} ; \mathrm{n}=4\right)\end{array}$ & $1.09 \pm 0.12$ & $2.13 \pm 0.09$ & $3.04 \pm 0.06$ & na & $6.70 \pm 0.34$ \\
\hline & $\begin{array}{l}\text { Predator SL } \\
\left(\mathrm{mm}_{;} \mathrm{n}=12\right)\end{array}$ & $40.5 \pm 0.2$ & $41.9 \pm 0.3$ & $39.8 \pm 0.2$ & na & $41.0 \pm 0.2$ \\
\hline \multirow[t]{2}{*}{$\begin{array}{l}\text { Naked goby: } \\
\text { amphipods }\end{array}$} & $\begin{array}{l}\text { Dissolved oxygen } \\
\left(\mathrm{mg} l^{-1} ; 1 \mathrm{n}=4\right)\end{array}$ & $0.99 \pm 0.04$ & $1.86 \pm 0.16$ & $2.83 \pm 0.02$ & na & $6.48 \pm 0.23$ \\
\hline & $\begin{array}{l}\text { Predator SL } \\
(\mathrm{mm} ; \mathrm{n}=12)\end{array}$ & $41.3 \pm 0.3$ & $41.3 \pm 0.3$ & $41.3 \pm 0.3$ & na & $41.3 \pm 0.3$ \\
\hline \multirow[t]{3}{*}{$\begin{array}{l}\text { Sea nettle: } \\
\text { larvae }\end{array}$} & $\begin{array}{l}\text { Dissolved oxygen } \\
\left(\mathrm{mg} \mathrm{I} \mathrm{I}^{-1} \mathrm{n}=7\right)\end{array}$ & $1.08 \pm 0.04$ & $2.09 \pm 0.03$ & $2.90 \pm 0.02$ & na & $6.67 \pm 0.29$ \\
\hline & $\begin{array}{l}\text { Predator bell } \\
\text { diameter }(m m ; n=7)\end{array}$ & $84.8 \pm 4.3$ & $93.2 \pm 5.4$ & $85.0 \pm 3.8$ & na & $90.3 \pm 4.1$ \\
\hline & $\begin{array}{l}\text { Predator volume } \\
(\mathrm{ml} ; \mathrm{n}=7)\end{array}$ & $88.3 \pm 12.2$ & $111.7 \pm 12.2$ & $91.7 \pm 8.3$ & na & $95.0 \pm 9.6$ \\
\hline
\end{tabular}


counted for $3 \mathrm{~min}$. Three replicates were completed for each target dissolved oxygen concentration; each fish was used for only a single observation. Gill ventilation rates of adult naked gobies were determined as part of a related study (Breitburg 1992). Aduit males and PVC tubes, which were used as nest and shelter sites, were placed individually in 1051 aquaria. After an initial observation, tanks were bubbled with a series of air: $\mathrm{N}_{2}$ mixtures that had decreasing percentages of oxygen, and finally with $100 \% \mathrm{~N}_{2}$ in order to decrease oxygen concentrations by approximately $1 \mathrm{mg} \mathrm{l}^{-1} \mathrm{~h}^{-1}$. Gill ventilation rates were counted for 10 s during each hourly observation when the fish was oriented in a manner that permitted an unobstructed view of its opercula. Because opercular movements were not always visible, the actual number of hourly counts on each of the 20 test fish and the oxygen concentrations at which each fish was observed varied. These data are therefore presented only to provide a qualitative impression of the response of adult naked gobies to decreasing oxygen concentrations.

Contraction rates of the medusa bell were measured for sea nettles. Increased bell contractions at low oxygen concentrations could increase the volume of water passing over their tissues, while decreased bell contraction rates might reduce the energetic costs of swimming. Either of these changes in swimming activity could influence encounter rates between sea nettles and their larval prey. We tested the effects of dissolved oxygen ('oxygen experiment') and the effects of repeated handling ('handling experiment') in nested repeated measures experiments with 2 sea nettles per $76 \mathrm{l}$ aquarium of $1.0 \mu \mathrm{m}$ filtered Patuxent River water. In the 4 oxygenexperiment aquaria, sea nettles were tested sequentially in air-saturated, $3 \mathrm{mg} \mathrm{l}^{-1}, 2 \mathrm{mg} \mathrm{l}^{-1}$, and $1 \mathrm{mg} \mathrm{l}^{-1}$ dissolved oxygen concentrations. To test the effects of handling and the order of oxygen treatments tested, sea nettles in 4 handling-experiment aquaria were repeatedly observed at approximately the same time intervals as experimental individuals, but all measurements were made in air-saturated water.

Sea nettles for these experiments were collected from the Patuxent River near Benedict, Maryland, by dip-net and held in $20 \mathrm{l}$ buckets of filtered river water. Sea nettles were acclimated to the test dissolved oxygen levels for a minimum of 15 min after which bell contractions of each individual were counted for 3 min. After the final count, bell diameter $(\mathrm{cm})$ and total volume ( $\mathrm{ml}$ ) were measured for each sea nettle.

To further examine the effect of low oxygen on predation by fish, we tested the ability of adult naked gobies to capture gammarid amphipods at nominal oxygen concentrations of $1.0,2.0$ and $3.0 \mathrm{mg} \mathrm{l}^{-1}$ dissolved oxygen and in an air-saturated control. We used a Latin square experimental design with groups of 3 adult naked goby in each tank. A total of 4 groups of 3 fish were rotated through each of the dissolved oxygen treatments such that each group of predators was tested once at each oxygen concentration. With this experimental design, each group of fish was exposed to the 4 dissolved oxygen treatments in a different temporal order, thus minimizing biases due to learning.

On the day of these experiments, adult gobies were transferred to four $20 \mathrm{l}$ tanks, each containing 3 oyster shells. The tanks were then sealed and bubbled with $100 \% \mathrm{~N}_{2}$ until desired dissolved oxygen levels were reached. After the gobies were acclimated for $1 \mathrm{~h}, 200$ field-collected gammarid amphipods were added to each tank. The adult gobies were allowed to feed for $4 \mathrm{~h}$, after which time they were removed, the tanks were drained, and amphipods were counted. Four replicates of each treatment were conducted. Adult naked gobies were maintained on adult brine shrimp between replicates.

\section{RESULTS}

\section{Juvenile striped bass}

Consumption of naked goby larvae by juvenile striped bass declined significantly at low dissolved oxygen levels (Table 3; Fig. 1a). Fewer than half the number of larvae were consumed at dissolved oxygen concentrations of $2 \mathrm{mg} \mathrm{l}^{-1}$ than at $3 \mathrm{mg} \mathrm{l}^{-1}$ or higher. A posteriori least-squares means comparisons (SAS 1988) indicated that consumption at $2 \mathrm{mg}^{-1}$ differed significantly from that at other tested oxygen concentrations.

Larval age and predator size both varied during the course of the experiment. Striped bass were tested on newly hatched through late postflexion larvae because they potentially overlap in distribution with the full age range of larvae in the field. Because our experimental striped bass were growing, predators in some of the

Table 3. Morone saxatilis preying on Gobiosoma bosc larvae. Results of randomized block ANOVA for effect of dissolved oxygen concentration on no. of larvae consumed by juvenile striped bass. Results of the a posteriori tests are given below; treatments not connected by a common underline differed at the $p<0.05$ level

\begin{tabular}{|c|c|c|c|c|c|}
\hline Source & $\mathrm{df}$ & \multicolumn{2}{|c|}{ Sums of squares } & $F$ & $\mathrm{p}$ \\
\hline $\begin{array}{l}\text { Dissolved } \\
\text { oxygen }\end{array}$ & 3 & \multicolumn{2}{|c|}{705.48} & 3.90 & 0.016 \\
\hline Block & 12 & \multicolumn{2}{|c|}{2289.48} & 3.17 & 0.004 \\
\hline \multicolumn{2}{|c|}{$\begin{array}{l}\text { Nominal oxygen } \\
\text { concentration: }\end{array}$} & 2 & 3 & \multicolumn{2}{|r|}{ Saturated } \\
\hline
\end{tabular}



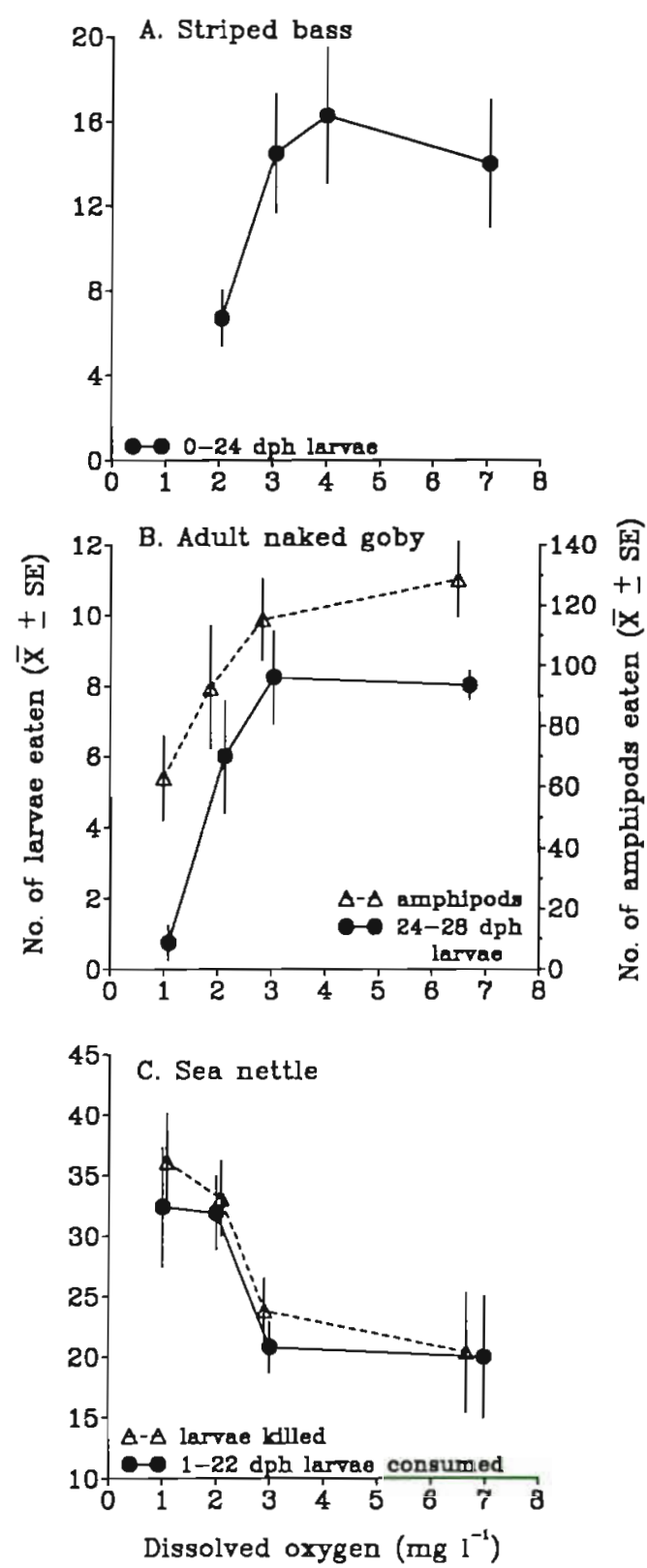

Fig. 1. Morone saxatilis, Gobiosoma bosc and Chrysaora quinquecirrha preying on $G$. bosc larvae. Numbers of prey consumed by juvenile striped bass, adult naked gobies and sea nettles under reduced and aur-saturated oxygen concentratjons. dph: days posthatch

later tests were slightly larger than those in tests run earlier in the summer. However, neither larval age nor predator size consistently affected the number of larvae consumed within dissolved oxygen treatments. Multiple regression analyses were run separately for each dissolved oxygen treatment with predator size and larval age as independent variables. Striped bass standard length explained nearly $50 \%$ of the variation in number of larvae consumed in the $3 \mathrm{mg} \mathrm{l}^{-1}$ dissolved oxygen treatment $\left(\mathrm{r}^{2}=0.49, F=9.56, \mathrm{p}=0.0114\right)$, but no other significant effects of predator size or larval age were found (all other $p>0.4$ ). Thus the significant block result of the initial ANOVA $(p=0.004)$ that tested for dissolved oxygen effects remains largely unexplained. Randomized block ANOVA also indicated that while striped bass standard length did not vary significantly among dissolved oxygen treatments, it did vary significantly among blocks (dissolved oxygen: $F=1.12, \mathrm{p}=0.354, \mathrm{df}=3$; block: $F=4.67, \mathrm{p}<$ $0.0003, \mathrm{df}=11$; Table 2).

Observations of experimental tanks indicated that the low dissolved oxygen concentrations tested affected the predatory behavior of juvenile striped bass. With decreasing concentrations of dissolved oxygen, striped bass first became agitated, swimming in short, erratic bursts uncharacteristic of their normal swimming behavior. As oxygen was reduced to $2 \mathrm{mg}$ $1^{-1}$, the fish became noticeably less active, often remaining motionless in a corner of the tank. In contrast, naked goby larvae appeared to swim normally even at $2 \mathrm{mg} \mathrm{l}^{-1}$, the lowest oxygen concentration tested with juvenile striped bass as predators. Gill ventilation rates also indicated that striped bass were under low oxygen stress even at oxygen concentrations with high predation rates. Ventilation rates were significantly higher at 2,3 and $4 \mathrm{mg} \mathrm{l}^{-1}$ than at air-saturated control oxygen concentrations ( 1 -way ANOVA: $F=33.81, \mathrm{p}<0.0001, \mathrm{df}=3$; Fig. $2 a)$.

\section{Adult naked goby}

Predation on larvae by adult naked gobies was significantly affected by dissolved oxygen concentration (Table 4; Fig. 1b). Numbers of larvae consumed decreased with decreasing oxygen concentration from a high of 8 larvae in air-saturated controls and $3 \mathrm{mg} \mathrm{l}^{-1}$ tanks to a low of 0.75 at $1 \mathrm{mg} \mathrm{l}^{-1}$. In a posteriori least-

Table 4. Gobiosoma bosc preying on G. bosc larvae. Results of randomized block ANOVA for effect of dissolved oxygen concentration on number of larvae consumed by adult naked gobies. Results of the a posteriori tests are given below; treatments not connected by a common underline differed at the $p<0.05$ level

\begin{tabular}{lccccc|}
\hline Source & df & Sums of squares & $F$ & $p$ \\
\hline $\begin{array}{l}\text { Dissolved } \\
\text { oxygen }\end{array}$ & 3 & 13.53 & 25.74 & 0.0001 \\
$\begin{array}{l}\text { Block } \\
\begin{array}{l}\text { Nominal oxygen } \\
\text { concentration: }\end{array}\end{array}$ & 1 & 2.15 & 4.09 & 0.0436 \\
\hline
\end{tabular}



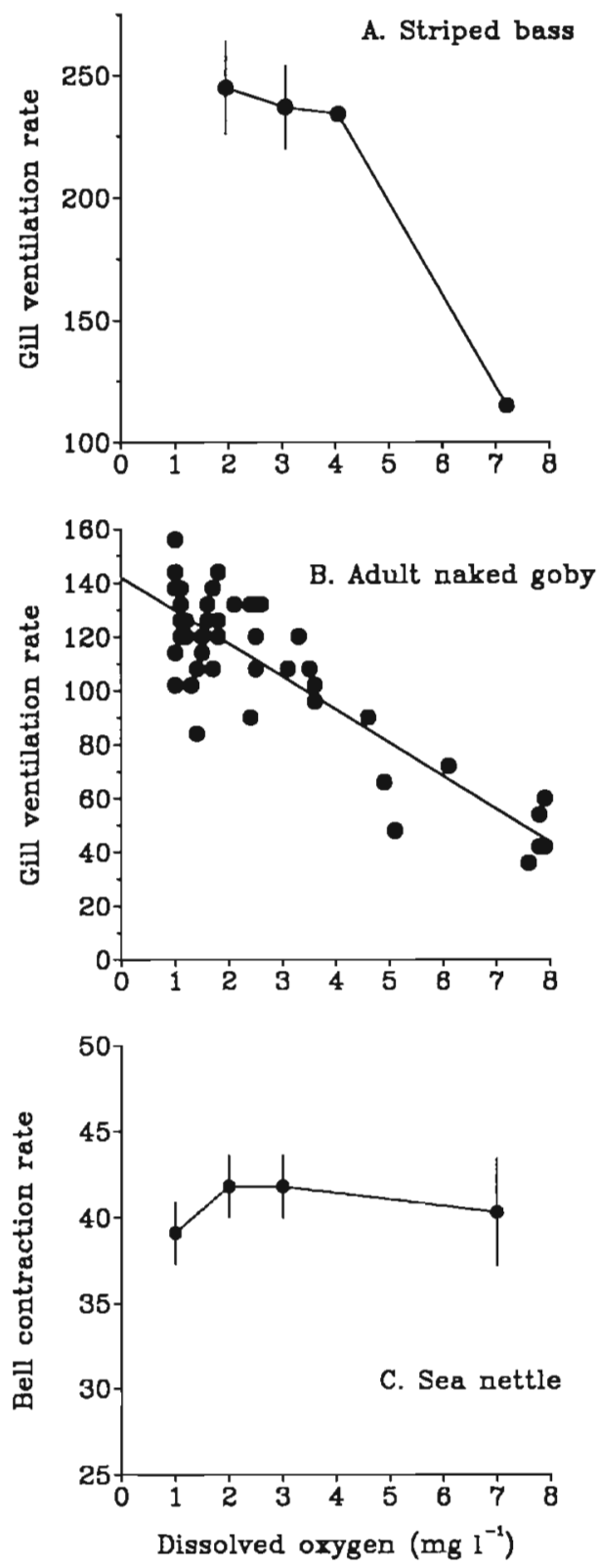

Fig. 2. Morone saxatilis, Gobiosoma bosc, Chrysaora quinquecirrha. Measures of physiological stress of predators exposed to low dissolved oxygen (no. of gill ventilations or bell contractions $\min ^{-1}$ ). The regression line fitted to the naked goby data is meant only to guide the eye. Data include multiple observations of several individuals, and are therefore not independent. However, no individual was observed more than once at a single dissolved oxygen concentration

squares means comparisons, only the $1 \mathrm{mg} \mathrm{l}^{-1}$ treatment differed significantly from other tested oxygen concentrations. However, there was a tendency towards decreased consumption at $2 \mathrm{mg} \mathrm{l}^{-1}$ dissolved oxygen as well. Dissolved oxygen concentrations and temperatures measured in experimental tanks are
Table 5. Gobiosoma bosc preying on amphipods. Results of Latin square ANOVA for effect of dissolved oxygen concentration on no. of gammarid amphipods consumed by adult naked goby. Results of the a posteriori tests are given below; treatments not connected by a common underline differed at the $p<0.05$ level

\begin{tabular}{lcccc|}
\hline Source & df & Sums of squares & $F$ & $\mathrm{p}$ \\
\hline $\begin{array}{l}\text { Dissolved } \\
\text { oxygen }\end{array}$ & 3 & 9939.19 & 7.93 & 0.017 \\
$\begin{array}{l}\text { Predator group } \\
\text { block } \\
\text { Date block }\end{array}$ & 3 & 4429.19 & 3.53 & 0.088 \\
$\begin{array}{l}\text { Nominal oxygen } \\
\text { concentration: }\end{array}$ & 1336.06 & 3.20 & 0.105 \\
\hline
\end{tabular}

given in Table 2. Randomized block ANOVA indicated that predator SL was similar among dissolved oxygen treatments and among blocks (dissolved oxygen: $F=$ $0.10, \mathrm{p}=0.955, \mathrm{df}=3$; block: $F=1.24, \mathrm{p}=0.350, \mathrm{df}=3$ Table 2).

Qualitative observations of experimental tanks indicated that adults became less active in the $1 \mathrm{mg} \mathrm{l}^{-1}$ treatment. In addition, gill ventilation rates of adult naked gobies rose steadily from air-saturated to $1 \mathrm{mg}$ $\mathrm{l}^{-1}$ oxygen concentrations (Fig. 2b). In some replicates of the $1 \mathrm{mg} \mathrm{l}^{-1}$ treatment, larvae were at the surface of the water, but all adults remained on or near the tank bottom.

Tests with gammarid amphipods support the observation of reduced predatory activity by adult naked gobies at low oxygen concentrations. The predation pattern on amphipods was similar to that found for predation on larvae (Table 5; Fig. 1b). Approximately half as many amphipods were consumed at $1 \mathrm{mg} \mathrm{l}^{-1}$ dissolved oxygen as at saturated oxygen levels. In a posteriori tests, consumption of amphipods was significantly lower at both $2 \mathrm{mg} \mathrm{l}^{-1}$ and $1 \mathrm{mg} \mathrm{l}^{-1}$ as compared to air-saturated levels.

\section{Sea nettle}

In contrast to results for the 2 predatory fishes, mortality and consumption of naked goby larvae in the presence of sea nettles increased at low oxygen concentrations (Tables 6 \& 7, Fig. 1c). Mortality of naked goby larvae exposed to sea nettle predators averaged 65 to $80 \%$ higher in the $2 \mathrm{mg} \mathrm{l}^{-1}$ and $1 \mathrm{mg} \mathrm{l}^{-1}$ treatments than in air-saturated controls. A posteriori leastsquares means comparisons indicated that the 1 and $2 \mathrm{mg} \mathrm{l}^{-1}$ dissolved oxygen treatments differed significantly from higher oxygen concentrations tested. Con- 
sumption of larvae by sea nettles also increased by approximately $60 \%$ in the $2 \mathrm{mg} \mathrm{l}^{-1}$ and $1 \mathrm{mg} \mathrm{l}^{-1}$ treatments as compared to controls. Analysis of variance indicated a significant effect of dissolved oxygen on consumption, and a posteriori comparisons indicated

Table 6. Chrysaora quinquecirrha preying on Gobiosoma bosc. Results of randomized block ANOVA for effect of dissolved oxygen concentration on larval mortality in the presence of sea nettles. Opaque dead larvae were included in the mortality estimates. Results of the a posteriori tests are given below; treatments not connected by a common underline differed at the $\mathrm{p}<0.05$ level

\begin{tabular}{lccccc|}
\hline Source & $\mathrm{df}$ & Sums of squares & $F$ & $\mathrm{p}$ \\
\hline $\begin{array}{l}\text { Dissolved } \\
\text { oxygen }\end{array}$ & 3 & 1196.87 & 5.69 & 0.007 \\
$\begin{array}{l}\text { Block } \\
\begin{array}{l}\text { Nominal oxygen } \\
\text { concentration: }\end{array}\end{array}$ & $\mathbf{1}$ & 1094.91 & & 2.60 & 0.056 \\
\hline
\end{tabular}

Table 7. Chrysaora quinquecirrha preying on Gobiosoma bosc. Results of randomized block ANOVA for effect of dissolved oxygen concentration on consumption of naked goby larvae by sea nettles. Opaque dead larvae were not included in consumption estimates. Results of the a posteriori least-squares means comparisons are given below; treatments not connected by a common underline differed at the $p<0.05$ level

\begin{tabular}{lccccc|}
\hline Source & df & Sums of squares & $F$ & $p$ \\
\hline $\begin{array}{l}\text { Dissolved } \\
\text { oxygen }\end{array}$ & 3 & 935.34 & 3.63 & 0.034 \\
$\begin{array}{l}\text { Predator group } \\
\text { block }\end{array}$ & 6 & 756.98 & 1.47 & 0.247 \\
$\begin{array}{l}\text { Nominal oxygen } \\
\text { concentration: }\end{array}$ & 1 & 2 & 3 & Saturated \\
\hline
\end{tabular}

Table 8. Chrysara quinquecirha. Results of nested ANOVAs testing for effect of dissolved oxygen concentration on bell contraction rates of sea nettles. Separate analyses were done for the control group (individuals maintained at saturated oxygen concentrations for each of the 4 observations) and the experimental group of animals (individuals subjected to decreasing oxygen concentrations during repeated observations)

\begin{tabular}{llcccc} 
& Source & df & Surns of squares & $F$ & $p$ \\
\hline Handling & Dissolved oxygen & 3 & 2.75 & 0.06 & 0.982 \\
experiment & Tank & 12 & 146.75 & 0.74 & 0.696 \\
Oxygen & Dissolved oxygen & 3 & 13.03 & 0.69 & 0.572 \\
experiment & Tank & 6 & 644.88 & 2.84 & 0.027 \\
\hline
\end{tabular}

significant differences among low and high oxygen concentration treatments.

Neither predator size nor larval age significantly affected the number of larvae consumed within dissolved oxygen treatments. In multiple regression analyses run separately for each dissolved oxygen treatment and the 2 measures of sea nettle size, bell diameter, sea nettle volume, and larval age did not significantly affect the number of larvae that died or were consumed (all $p>$ 0.05). Randomized block ANOVAs also indicated that neither bell diameter nor sea nettle volume varied significantly among dissolved oxygen treatments (diameter: $F=1.01, \mathrm{p}=0.293$, df $=3$; volume: $F=1.37, \mathrm{p}=$ $0.2906, \mathrm{df}=3$ ) but bell diameter did vary significantly among blocks (diameter: $F=2.46, \mathrm{p}=0.033$, df $=5$; volume: $F=2.86, \mathrm{p}<0.0521, \mathrm{df}=5$; Table 2).

Unlike results for the 2 fish predators, our measure of oxygen stress in the sea nettle was unaffected by dissolved oxygen even at concentrations as low as $1 \mathrm{mg}$ $1^{-1}$. Sea nettles averaged $41.2 \pm 0.6$ bell contractions min $^{-1}$ for all observations combined ( $n=64$ ). Bell contraction rates were similar at all dissolved oxygen concentrations, with treatment means ranging from 39 to 42 contractions min $^{-1}$ (Table 8, Fig. 2). Handling also had no effect on bell contraction rates; the difference between mean contraction rates for the first and final measurement periods was $<1$ contraction $\mathrm{min}^{-1}$, and there were no significant differences between any of the observation periods (Table 8 ).

\section{DISCUSSION}

Our results suggest that both the relative and absolute importance of vertebrate and invertebrate predators of fish larvae can by altered under low dissolved oxygen concentrations. Low dissolved oxygen concentrations modified the behavior of both predators and their prey, and therefore the vulnerability of larvae to predation. Effects of low oxygen on predation on fish larvae is particularly important because predation may be the major cause of mortality during the early life stages of fishes (Bailey \& Houde 1989) and has the potential to be a regulating factor in the recruitment process (Sissenwine 1984).

Low oxygen appeared to have somewhat different effects on the behavior of each species and life stage tested. These varying responses were reflected in variation in the magnitude and direction of the effect of low oxygen on consumption of fish larvae. Predation by the 2 vertebrate predators at $2 \mathrm{mg} \mathrm{l}^{-1}$ oxygen concentration 
was 25 to $50 \%$ lower than at air-saturated levels. In contrast, larval consumption by the scyphomedusa increased by more than half at the same $2 \mathrm{mg} \mathrm{l}^{-1}$ oxygen level.

Of the predators tested, striped bass was the most sensitive to low oxygen concentrations. Gill ventilation increased significantly even at $4 \mathrm{mg} \mathrm{l}^{-1}$ oxygen concentrations, although fish continued to capture prey at a high rate at $4 \mathrm{mg} \mathrm{l}^{-1}$. These results suggest that juvenile striped bass become physiologically stressed at oxygen concentrations that are quite high relative to those found in many areas of Chesapeake Bay during summer. Other studies indicate similar sensitivity of juvenile striped bass and suggest that dissolved oxygen concentrations of at least $3 \mathrm{mg} \mathrm{l}^{-1}$ are required for survival (Setzler-Hamilton \& Hall 1991).

The direct effect of low oxygen on the attack rate of juvenile striped bass is the most likely cause of the $50 \%$ decrease in consumption of larvae at $2 \mathrm{mg} \mathrm{l}^{-1}$ in our experiments. At $2 \mathrm{mg} \mathrm{l}^{-1}$ dissolved oxygen, juvenile striped bass often appeared lethargic or remained motionless. In contrast, we observed no change in larval behavior that would decrease their susceptibility to predation at $2 \mathrm{mg} \mathrm{l}^{-1}$. Appetite depression under low oxygen conditions has been previously noted in laboratory feeding trials with artificial diets (Setzler-Hamilton \& Hall 1991).

Adult naked gobies are generally more tolerant of low dissolved oxygen than are striped bass. Field sampling and laboratory experiments indicate that oxygen concentrations as low as $0.75 \mathrm{mg} \mathrm{l}^{-1}$ would not affect survival, large-scale movement, or nest-site fidelity during exposure durations 2 to 3 times the length of those used in our predation experiments (Breitburg 1992). Nevertheless, adult naked gobies did exhibit increased gill ventilation rates and decreased consumption at 1 and $2 \mathrm{mg} \mathrm{l}^{-1}$ - oxygen concentrations that frequently occur in moderate and deep areas of mesohaline Chesapeake oyster reefs (Sanford et al. 1990).

Decreased attack rates by adult naked gobies most likely explain the decreased consumption of gammarid amphipods at 1 and $2 \mathrm{mg} \mathrm{l}^{-1}$, and the trend towards decreased consumption of naked goby larvae at $2 \mathrm{mg}$ $\mathrm{l}^{-1}$ dissolved oxygen. In our experimental tanks, amphipods had no effective escape from predators and remained on the bottom of the tanks at all oxygen concentrations tested. Amphipod activity did not appear to change with dissolved oxygen concentration. Thus changes in consumption of this prey were most likely due to low oxygen-induced changes in behavior of the predator, not to changes in amphipod behavior. As indicated above, we also saw no obvious change in larval behavior that would contribute to decreased frequency of success of attacks by fish predators at $2 \mathrm{mg} \mathrm{l}^{-1}$. However, at $1 \mathrm{mg} \mathrm{l}^{-1}$, the lowest oxygen con- centration tested, different behaviors of adults and larvae led to spatial separation of the predator and some prey in addition to altered predatory behavior. In the $1 \mathrm{mg} \mathrm{l}^{-1}$ treatment, we observed larvae at the water surface, presumably respiring in the surface film. Observations in this study, more detailed observations in other laboratory experiments (Breitburg 1992), and field observations (Breitburg unpubl.) indicate that adult naked gobies do not employ aquatic surface respiration until oxygen concentrations fall well below 1 $\mathrm{mg} \mathrm{l}^{-1}$. The tendency for larvae to move to the surface at $1 \mathrm{mg} \mathrm{l}^{-1}$ also may explain why predation on larvae declined more sharply than predation on amphipods tested at the same oxygen concentration

The sea nettle is considerably more tolerant of low dissolved oxygen concentrations than are either of the vertebrate predators we tested, indicating that increased larval consumption at low dissolved oxygen results from impaired ability of larvae to escape or avoid attack. In $96 \mathrm{~h}$ tests, sea nettle survival was $100 \%$ at $1 \mathrm{mg} \mathrm{l}^{-1}$ during the initial $24 \mathrm{~h}$ period, exhibited a $96 \mathrm{~h} \mathrm{LC}_{50}$ of $0.72 \mathrm{mg} \mathrm{l}^{-1}$ (C. E. Zastrow, E. D. Houde \& L. Linley unpubl.). Furthermore, bell contraction rates did not change as oxygen concentrations varied between $1 \mathrm{mg} \mathrm{l}^{-1}$ and air-saturated levels. In other experiments with $1 \mathrm{~h}$ acclimation periods to match predation experiments, bell contraction were similar at $1.5 \mathrm{mg}^{-1}$ dissolved oxygen and in air-saturated controls (Breitburg \& Pacey unpubl. data). If tentacle extension also remained similar, these results suggest that the ability of sea nettles to capture prey and the volume of water they 'search' for prey is unaffected by oxygen concentrations as low as $1 \mathrm{mg} \mathrm{l}^{-1}$. It is likely that low oxygen has a greater effect on the swimming behavior of fish larvae than that of sea nettles, and that this difference results in increased larval consumption at low dissolved oxygen concentrations.

Several mechanisms could lead to the observed increase in larval consumption by sea nettles at low oxygen concentrations. A decrease in active avoidance, or a decrease in the ability of larvae to survive contact with the sea nettle are possible. However, we consider a third explanation to be more likely. If larvae swim more slowly or weakly when stressed by low oxygen, they may be more susceptible to being passively swept into the medusa's tentacles by vortices created by contractions of the bell (Costello in press, unpubl. data). If bell contraction strength, like the measured bell contraction rate, is unchanged by oxygen concentrations $\geq 1 \mathrm{mg} \mathrm{l}^{-1}$, this mechanism would increase the capture rate of larvae at low oxygen concentrations. Our visual observations of larvae during predation experiments were designed only to detect gross changes in position and swimming ability, and would not have detected changes in swimming speed. 
The importance of the altered predator-prey interactions demonstrated in our experiments will depend upon how vertical gradients in dissolved oxygen affect the distributions and co-occurrences of prey and their predators. Both laboratory experiments and preliminary analysis of field data suggest that even goby larvae $<1$ dph strongly avoid oxygen concentrations $\leq 1 \mathrm{mg} \mathrm{l}^{-1}$, which are lethal during $24 \mathrm{~h}$ exposures (Breitburg unpubl.). However, altered trophic interactions that were observed at oxygen concentrations near $2 \mathrm{mg} \mathrm{l}^{-1}$ are likely to be important to naked goby larvae. Laboratory experiments that investigated the behavioral response of larvae to low oxygen in the absence of predators indicated that naked goby larvae potentially could be abundant in bottom waters with $2 \mathrm{mg} \mathrm{l}^{-1}$ dissolved oxygen, although expected densities would be lower than where bottom oxygen concentrations are near saturation (Breitburg unpubl., Houde \& Breitburg unpubl. data). Experiments with mayfly larvae indicate that these invertebrates select low oxygen environments to avoid predators (Rahel \& Kolar 1990). If overall predation rates in the Chesapeake Bay system are lower at $2 \mathrm{mg} \mathrm{l}^{-1}$ than at higher dissolved oxygen concentrations, goby larvae might increase their use of this low oxygen zone above that observed in our predator-free experiments in order to reduce predation risk.

Of the 3 predators tested, naked goby adults and sea nettles are likely to be abundant at oxygen concentrations that lead to altered prey consumption rates. Adult naked gobies are abundant in environments that at least periodically experience oxygen concentrations of $\leq 2 \mathrm{mg} \mathrm{l}^{-1}$ (Breitburg 1992). Densities of adults and juveniles on Chesapeake Bay oyster reefs can exceed 40 ind. $\mathrm{m}^{-2}$. Predation by resident adults on demersal and settling larvae could be an important factor limiting density of recruits. Oxygen concentrations that are sufficiently low to periodically reduce predatory activity of benthic residents, but do not induce larvae to move higher in the water column, may thus provide windows of time with increased survival of demersal larvae, and perhaps increased successful settlement onto oyster reefs.

The increase in vulnerability of fish larvae to predation by the sea nettle at oxygen concentrations of 1 and $2 \mathrm{mg} \mathrm{l}^{-1}$ may also be quite important in the field. Preliminary data from field samples indicate that sea nettles occur in bottom waters even when oxygen concentrations are below $1 \mathrm{mg} \mathrm{l}^{-1}$ (Kiester, Houde \& Breitburg unpubl. data). Sea nettles are important predators of fish larvae in well-oxygenated surface waters (Cowan \& Houde 1992, 1993). It is probable that their importance relative to other planktonic predators increases under reduced oxygen concentrations.
In contrast to the importance of oxygen to consumption by adult naked gobies and sea nettles, the potential decrease in consumption of fish larvae by juvenile striped bass is unclear. In experiments described here, we found decreased consumption of larvae only at $2 \mathrm{mg} \mathrm{l}^{-1}$, a level that may rarely be experienced in the field since striped bass avoid oxygen concentrations below $4 \mathrm{mg} \mathrm{l}^{-1}$ (Coutant \& Benson 1988). However, the small container size used in our experiments may have limited our ability to detect effects of dissolved oxygen on striped bass feeding behavior. Experiments conducted in $1 \mathrm{~m}^{3}$ mesocosms with lower prey densities, and presumably increased energetic costs of prey capture, resulted in decreased capture rates at oxygen concentrations that juvenile striped bass do not strongly avoid (Breitburg unpubl. data).

Intrinsic physical features (depth, freshwater inflow, etc.) lead to some degree of oxygen depletion in the absence of human influence in many severely affected systems including the Chesapeake Bay (May 1973, Turner et al. 1987, Seliger \& Boggs 1988, Malone 1992). Subpycnocline water in the mesohaline Chesapeake Bay was probably no higher than $2 \mathrm{mg} \mathrm{l}^{-1}$ during summer, even under pristine conditions (D. Pritchard pers. comm.). Furthermore, even optimistic estimates suggest that nutrient reduction in Chesapeake Bay will lead to very modest increases in subpycnocline dissolved oxygen concentrations and will not increase bottom dissolved oxygen above $2 \mathrm{mg} \mathrm{l}^{-1}$ during summer (Jordan et al. 1992). It is therefore significant that the critical dissolved oxygen concentration leading to altered prey consumption rates by both vertebrate and invertebrate predators in our experiments was between 2 and $3 \mathrm{mg} \mathrm{l}^{-1}$. Altered predatorprey interactions in the mesohaline Bay food web are likely to be important under both present and potentially improved conditions.

Acknowledgements. We thank L. Linley and C. Zastrow for help in culturing organisms and laboratory experiments, and C. Pacey for conducting the bell contraction rate experiments This research was funded by University of Maryland Sea Grant awards R/P-29 and R/P-29B to D.L.B. and E.D.H. Participation in this research by N.S. and S.D. was funded by a NSF Research Experience for Undergraduates site awards OCE-8900707 and OCE-9100611 to the University of Maryland Sea Grant Program. We also thank the Potomac Electric Power Company for providing juvenile striped bass used in our experiments.

\section{LITERATURE CITED}

Academy of Natural Sciences (1981). Chalk Point 316 Demonstration of thermal, entrainment and impingement impacts on the Patuxent River, Vol. III. Academy of Natural Sciences, Philadelphia, Report No. $81-5$ 
Allen, D. M., Barker, D. L. (1990). Interannual variations in larval fish recruitment to estuarine epibenthic habitats. Mar. Ecol. Prog. Ser. 63: 113-125

Bailey, K. M., Houde, E. D. (1989). Predation on early developmental stages of marine fishes and the recruitment problem. Adv. mar. Biol. 25: 1-83

Baird, D., Ulanowicz, R. E. (1989). The seasonal dynamics of the Chesapeake Bay ecosystem. Ecol. Monogr. 59: 329-364

Boesch, D. F. (1987). Eutrophication of shelf waters in the northern Gulf of Mexico: influence of nutrient additions from the Mississippi River. In: Pollution and the coastal environment: a symposium. University of Maryland Sea Grant, College Park, p. 67-69

Boynton, W. R., Polgar, T. T., Zion, H. (1981). Importance of juvenile striped bass food habits in the Potomac Estuary. Trans. Am. Fish. Soc. 110; 56-63

Breitburg, D. L. (1988). Oxygen fluctuations and fish population dynamics in a Chesapeake Bay oyster bed. In: Lynch, M. P., Krome, E. C. (eds.) Understanding the estuary: recent advances in Chesapeake Bay research. Chesapeake Research Consortium, Inc., Gloucester Pt., VA, p. 547-557

Breitburg, D. L. (1989). Demersal schooling prior to settlement by larvae of the naked goby. Environ. Biol. Fish. 26: $97-103$

Breitburg, D. L. (1991). Settlement patterns and presettlement behavior of the naked goby, Gobiosoma bosci. Mar. Biol. 109: 213-221

Breitburg, D. L. (1992). Episodic hypoxia in the Chesapeake Bay: interacting effects of recruitment, behavior and physical disturbance. Ecol. Monogr. 62: 525-546

Cargo, D. G., Schultz, L. P. (1966). Notes on the biology of the sea nettle, Chrysaora quinquecirrha, in Chesapeake Bay. Chesapeake Sci. 7: 95-100

Cargo, D. G., Schultz, L. P. (1967). Further observations on the biology of the sea nettle and jellyfishes in Chesapeake Bay. Chesapeake Sci. 8: 209-220

Costello, J. H. (in press). Foraging energetics in hydromedusae. Sci. Mar.

Coutant, C. C., Benson, D. L. (1988). Linking estuarine water quality and impacts on living resources: shrinking striped bass habitat in Chesapeake Bay and Albemarle Sound. U.S. Environmental Protection Agency, Washington, DC, EPA 503/3-88-001

Cowan, J. G. Jr, Houde, E. D. (1992). Size-dependent predation on marine fish larvae by ctenophores, scyphomedusae, and planktivorous fish. Fish. Oceanogr. 1. 113-126

Cowan, J. G. Jr, Houde, E. D. (1993). The relative predation potentials of scyphomedusae, ctenophores and planktivorous fish on ichthyoplankton in Chesapeake Bay. Mar. Ecol. Prog. Ser. 95: 55-65

Dalton, P. (1987). Ecology of Anchoa mitchilli eggs and larvae in the mid-Chesapeake Bay. M.S. thesis, Univ. Maryland, College Park

Elngren, R. (1989). Man's impact on the ecosystem of the Baltic Sea: energy flows today and at the turn of the century. Ambio 18: 326-332

Feigenbaum, D., Kelly, M. (1984). Changes in the lower Chesapeake Bay food chain in presence of the sea nettle Chrysaora quinquecirrha (Scyphomedusae). Mar. Ecol. Prog. Ser. 19: 39-47

Houde, E. D. (1977). Food concentration and stocking density effects on survival and growth of laboratory-reared larvae of bay anchovy Anchoa mitchilli and lined sole Achirus lineatus. Mar. Biol. 43: 333-341

Houde, E. D. (1978). Critical food concentrations for larvae of three species of subtropical marine fishes. Bull. mar. Sci. 28: $395-411$

Jordan, S., Stenger, C., Olson, M., Batiuk, R., Mountford, K. (1992). Chesapeake Bay dissolved oxygen goal for restoration of living resources habitats. Chesapeake Bay Program Rpt CBP/TRS-88-93. Maryland Dept of Natural Resources, Annapolis

Kemp, W. M., Boynton, W. R. (1981). External and internal factors regulating metabolism rates of an estuarine benthic community. Oecologia 51: 19-27

Kennedy, V. S. (1990). Anticipated effects of climate change on estuarine and coastal fisheries. Fisheries 16: 16-24

Kramer, D. L. (1987). Dissolved oxygen and fish behavior. Environ. Biol. Fish. 18: 81-92

Magnien, R., Siegfried, R., Summers, R. (1987). Chemical and physical monitoring of the Chesapeake Bay mainstem and tributaries. In: Lynch, M. P., Krome, E. C. (eds.) State of the Chesapeake Bay Second Annual Monitoring Report Compendium. Chesapeake Research Consortium, Inc., Gloucester Point, VA, p. 3-20

Magnuson, J. J., Beckel, A. L., Mills, K., Brandt, S. B. (1985). Surviving winter hypoxia: behavioral adaptations of fishes in a northern Wisconsin winterkill lake. Environ. Biol. Fish. 14: 241-250

Malone, T C. (1992). Effects of water column processes on dissolved oxygen: nutrients, phytoplankton and zooplankton. In: Smith, D., Leffler, M., Mackiernan, G. (eds.) Oxygen dynamics in Chesapeake Bay: a synthesis of recent research. Maryland Sea Grant College, University of Maryland, College Park, p. 61-148

Malone, T C., Kemp, W. M., Ducklow, H. W., Boynton, W. R., Tuttle, J. H., Jonas, R. B. (1986). Lateral variation in the production and fate of phytoplankton in a partially stratified estuary. Mar. Ecol. Prog. Ser. 32: 149-160

Markle, D. F., Grant, G. C. (1970). The summer food habits of young-of-year striped bass in three Virginia rivers. Chesapeake Sci. 11: $50-54$

Massman, W. H., Norcross, J. J., Joseph, E. B. (1963). Distribution of larvae of the naked goby, Gobiosoma bosci, in the York River. Chesapeake Sci. 4: 120-125

May, E. B. (1973). Extensive oxygen depletion in Mobile Bay, Alabama. Limnol. Oceanogr. 18: 353-366

Nero, L. L. (1976). The natural history of the naked goby Gobiosoma bosci (Perciformes: Gobiidae). M.Sc. thesis, Institute of Oceanography, Old Dominion University, Norfolk, VA

Officer, C. B., Biggs, R. B., Taft, J. L., Cronin, L. E., Tyler, M. A., Boynton, W. R. (1984). Chesapeake Bay anoxia: origin, development and significance. Science 223: 22-27

Olney. J. E. (1983). Eggs and early larvae of the bay anchovy, Anchoa mitchilli and the weakfish, Cynoscion regalis, in lower Chesapeake Bay with notes on associated ichthyoplankton. Estuaries 6: 20-35

Osman, R. W., Abbe G. R., Breitburg, D. L. (1990). Reduction in oyster recruitment as a consequence of periodic exposure to low-oxygen water. In: Mihursky, J. A., Chaney, A. (eds.) New perspectives in the Chesapeake System: a research and management partnership. Chesapeake Research Consortium Publication no. 137, Solomons, p. 193-200

Pihl, L., S. P. Baden, R. J. Diaz, Schaffner, L. C. (1992). Hypoxia-induced structural changes in the diet of bottomfeeding fish and crustacea. Mar. Biol. 112: 349-361

Poulin, R., Wolf, N. G., Kramer, D. L. (1987). The effect of hypoxia on the vulnerability of guppies (Poecilia reticulata, Poeciliidae) to an aquatic predator (Astronotus ocellatus, Cichlidae). Environ. Bíol. Fish. 20: 285-292 
Price, K. S., Flemer, D. A., Taft, J. L., Mackiernan, G. B., Nelsen, W. Biggs, R. B., Burger, N. H., Blaylock, D. A. (1985). Nutrient enrichment of Chesapeake Bay and its impact on the habitat of striped bass: a speculative hypothesis. Trans. Am. Fish. Soc. 14: 97-106

Purcell, J. E. (1984). Predation on fish larvae by Physalia physalis, the Portuguese man of war. Mar. Ecol. Prog. Ser. 19: $189-191$

Purcell, J. E. (1985). Predation on fish eggs and larvae by pelagic cnidarians and ctenophores. Bull. mar. Sci. 37 : $739-755$

Purcell, J. E. (1992). Effects of predation by the scyphomedusan Chrysaora quinquecirrha on zooplankton populations in Chesapeake Bay, USA. Mar. Ecol. Prog. Ser. 87: 65-76

Purcell, J. E., Grover, J. J. (1990). Predation and food limitation as causes of mortality in larval herring at a spawning ground in British Columbia. Mar. Ecol. Prog. Ser. 59: 55-61

Rabalais, N. N., Turner, R. E., Wiseman, W. J. Jr, Boesch, D. F. (1991). A brief summary of hypoxia on the northern Gulf of Mexico continental shelf: 1985-1988. In: Tyson, R. V., Person, T. H. (eds.) Modern and ancient continental shelf anoxia. Geological Society Special Pub. \#58, The Geological Society, London, p. 35-47

Rahel, F. J., Kolar, C. S. (1990). Trade-offs in the response of mayflies to low oxygen and fish predation. Oecologia 84: $39-44$

Renaud, M. L. (1986). Hypoxia in Louisiana coastal waters during 1983: implication for fisheries. Fish. Bull. U.S. 84 $19-26$

Rogers, B. A., Westin, D. T., Saila, S. B. (1982). Development of techniques and methodology for the laboratory culture of striped bass, Morone saxatilis (Waldbaum). U.S. Environmental Protection Agency, Narragansett

Rombough, P. J. (1988). Respiratory gas exchange, aerobic metabolism, and effects of hypoxia during early life. In: Hoar, W. S., Randall, D. J. (eds.) Fish physiology, Vol. XI, The physiology of developing fish. A. Eggs and larvae. Academic Press, San Diego, p. 59-161

Rosenberg, R., Elmgren, R., Fleischer, S., Jonsson, P., Persson, G., Dahlin, H. (1990). Marine eutrophication case studies in Sweden: a synopsis. Ambio 19: 102-108

Saint-Paul, U., Soares, G. M. (1987). Diurnal distribution and behavioral responses of fishes to extreme hypoxia in an

This article was presented by J. E. Purcell, Cambridge, Maryland, USA
Amazon floodplain lake. Environ. Biol. Fish. 20:91-104

Sanford, L. P., Sellner, K. G., Breitburg, D. L. (1990). Covariability of dissolved oxygen with physical processes in the summertime Chesapeake Bay. J. mar. Res. 48: 567-590

SAS (1988). SAS/STAT user's guide. SAS Inst., Inc., Cary, NC

Seliger, H. H., Boggs, J. A. (1988). Long term pattern of anoxia in the Chesapeake Bay. In: Lynch, M. P., Krome, E. C. (eds.) Understanding the estuary: advances in Chesapeake Bay research. Chesapeake Research Consortium, Solomons, p. 570-583

Setzler-Hamilton, E. M., Hall, L. Jr (1991). Striped bass. In Funderburk, S. L., Mihursky, J. A., Jordan, S. J., Riley, D. (eds.) Habitat requirements for Chesapeake Bay living resources. Chesapeake Bay Program, Annapolis, p. 13-31

Shenker, J. M., Hepner, D. J., Frere, P. E., Currence, L. E., Wakefield, W. W. (1983). Upriver migration and abundance of naked goby (Gobiosoma bosci) larvae in the Patuxent River estuary, Maryland. Estuaries 6: 36-42

Siefert, R. E., Spoor, W. A. (1974). Effects of reduced oxygen on embryos and larvae of the white sucker, coho salmon, brook trout and walleye. In: Blaxter, J. H. S. (ed.) The early life history of fish. Springer-Verlag, New York, p. 487-495

Sissenwine, M. P. (1984). Why do fish populations vary? In: May, R. (ed.) Exploitation of marine communities. Springer-Verlag, Berlin

Suthers, I. M., Gee, J. H. (1986). Role of hypoxia in limiting diel spring and summer distribution of juvenile yellow perch (Perca flavescens) in a prairie marsh. Can. J. Fish. Aquat. Sci. 43: 1562-1570

Swanson, R. L., Parker, C. A. (1988). Physical environmental factors contributing to recurring hypoxia in the New York Bight. Trans. Am. Fish. Soc. 117: 37-47

Turner, R. E., Shroeder, W. E., Wiseman, W. J. Jr (1987). The role of stratification in the deoxygenation of Mobile Bay and adjacent shelf bottom waters. Estuaries 19: 13-20

US-EPA. (1986). Ambient water quality criteria for dissolved oxygen. Office of Water Regulations and Standards, Criteria and Standards Division, Washington, DC, EPA 440/586-003

van der Veer, H. W., Bergman, M. J. N. (1986). Development of tidally related behaviour of a newly settled 0-group plaice (Pleuronectes platessa) population in the western Wadden Sea. Mar. Ecol. Prog. Ser. 31: 121-129

Manuscript first received: May 1, 1993

Revised version accepted: November 1, 1993 